\title{
O LOBBY E A LEI
}

\section{Hélio Sílvio Ourém Campos ${ }^{1}$}

Inicialmente, registro que entendo o termo lobby como uma série de atividades que buscam exercer pressão, direta ou indireta, sobre os poderes públicos, pretendendo, com isto, postular interesses não necessariamente empresariais, embora rotineiramente o sejam.

Quando se fala em poderes públicos, aí inseridos o Legislativo, o Executivo, e, também, o Judiciário.

Esclareço, ainda, que, ao falar em "o lobby e a lei”, embora, naturalmente, reconheça que o processo de elaboração legislativa seja uma etapa sujeita aos grupos de pressão, o que, por ora, mais irá me interessar é a possibilidade do lobby no ato de aplicação da lei, pois, afinal, a lei, mais do que a sua expressão literal, é o comando que os órgãos judiciais derradeiros, ou aqueles que produzem a coisa julgada, entendem que ela efetivamente o seja.

Um assunto delicado, mas que, inclusive no Brasil, precisa ser estudado.

Nos tempos atuais, e quem sabe sempre foi assim em menor ou maior grau, a informação e a influência são irmãs.

No entanto, não se trata, necessariamente, de algo ilícito, nem mesmo na esfera judicial. Contudo, poderá assumir uma fisionomia de absoluta irregularidade, quando pretende associar-se à venda de decisões, pois aí não apenas se está a discutir a corrupção no Judiciário, mas também uma singular exploração de prestígio, gratuita ou remunerada.

Ministros, Desembargadores, Juízes já foram objeto de investigações desta ordem; daí não ser possível ignorar o tema, pois isto enfraquece a autoridade em que se fundamenta as decisões judiciais.

Como justificativa à corrupção ou à prevaricação judicial pode-se apontar os excessos de ambição, de necessidades de consumo, deficiências familiares e pessoais, abandono ou relativização da ética, garantia de impunidade, aceitação ou passividade social etc.

Contudo, não se aponte o concurso público como o culpado. Certamente, não o é. Não encontro na má avaliação dos candidatos a origem do mal. Aliás, se defeitos existem no instituto do concurso público, e é natural que os haja também em relação aos aplicados aos

\footnotetext{
1 Doutorado em Direito pela Universidade de Lisboa, Portugal(2002) Colaborador da Escola da Magistratura do Estado de Pernambuco, Brasil. E-mail: ouremcampos@ hotmail.com.
} 
cargos da magistratura, estadual ou federal, o caminho não parece ser aboli-lo; mas aperfeiçoá-lo a cada dia.

Por outro lado, é equivocado imaginar-se que o único modo de ingresso na magistratura brasileira seja o concurso. Não o é.

Aliás, o critério constitucional de investidura, através de concurso público, aplica-se apenas para a primeira instância, entendida aí o primeiro grau ou o grau inicial das decisões, conforme dispõe o artigo 93, inciso I, da Constituição Federal de 1988, vejamos:

Art. 93. Lei complementar, de iniciativa do Supremo Tribunal Federal, disporá sobre o Estatuto da Magistratura, observados os seguintes princípios: I- ingresso na carreira, cujo cargo inicial será o de juiz substituto, através de concurso público de provas e títulos, com a participação da Ordem dos Advogados do Brasil em todas as suas fases, obedecendo-se, nas nomeações, à ordem de classificação.

Além disto, é imperativo constitucional a participação da Ordem dos Advogados do Brasil em todas as suas fases. Mais: as nomeações devem observar a ordem de classificação.

Assim, embora possam existir defeitos neste critério de investidura, creio que não seja o efetivo motivador das supostas vendas de decisões. É claro que questões incidentais podem ser aperfeiçoadas, tais como prestigiar-se mais a experiência do candidato do que a sua mera capacidade de memorização; não permitir que um examinador, convocado para a Banca pelos seus reconhecidos conhecimentos em uma disciplina jurídica (direitos canônico ou romano, p. ex.), venha a analisar os candidatos em outra bastante diversa (tributário ou administrativo).

O fato de o concurso não ser o elemento vetor não significa dizer que não possa recrutar pessoas que não sejam imunes a desvios de conduta. Mas parece ser um instrumento com filtros mais ou menos eficazes.

Ainda como critério de investidura, tem-se, no Brasil, o critério da escolha política, quer partidária ou associativa. Refiro-me ao quinto constitucional dos desembargadores dos Tribunais de Justiça e dos Tribunais Regionais Federais (art. 94, CF/88), ao terço constitucional dos ministros do Superior Tribunal de Justiça (art. 104, Par. Único, inc. II, CF/88) e à ampla liberdade de escolha dos ministros do Supremo Tribunal Federal (art. 101, $\mathrm{CF} / 88)$.

Veja-se o registro deste dispositivo constitucional:

Art. 94. Um quinto dos lugares dos Tribunais Regionais Federais, dos Tribunais dos Estados, e do Distrito Federal e Territórios será composto de membros do Ministério Público, com mais de dez anos de carreira, e de advogados, de notório saber jurídico 
e de reputação ilibada, com mais de dez anos de efetiva atividade profissional, indicados em lista sêxtupla pelos órgãos de representação das respectivas classes.

Parágrafo Único. Recebidas as indicações, o tribunal formará lista tríplice, enviando-a ao Poder Executivo, que, nos vinte dias subseqüentes, escolherá um de seus integrantes para nomeação.

Note-se, portanto, mais um critério de investidura, agora para juízes de segundo grau, que, além da competência originária, detêm a recursal, de modo a confirmar ou reformar as decisões dos juízes de primeiro grau, aqueles provenientes dos concursos públicos.

Seria uma espécie de critério misto, pois, inicialmente, associativo; e, após, políticopartidário, em face da necessidade de envio ao Poder Executivo para fazer a escolha final.

É evidente que, a partir de qualquer critério, pessoas isentas, equilibradas e competentes poderão surgir; mas é fundamental que a sociedade volte os olhos para todos os critérios de investidura.

Atente-se para mais um deles, agora dirigido aos Ministros, juízes que funcionam como o terceiro grau do Judiciário brasileiro.

Art. 104. O Superior Tribunal de Justiça compõe-se de, no mínimo, trinta e três Ministros.

Parágrafo Único. Os Ministros do Superior Tribunal de Justiça serão nomeados pelo Presidente da República, dentre brasileiros com mais de trinta e cinco e menos de sessenta e cinco, de notável saber jurídico e reputação ilibada, depois de aprovada a escolha pelo Senado Federal, sendo: I- um terço dentre juízes dos Tribunais Regionais Federais e um terço dentre desembargadores dos Tribunais de Justiça, indicados em lista tríplice elaborada pelo próprio Tribunal; II- um terço, em partes iguais, dentre advogados e membros do Ministério Público Federal, Estadual, do Distrito Federal e Territórios, alternadamente, indicados na forma do art. 94.

Aqui, não basta destacar o critério misto, associativo e político-partidário. É preciso, também, a reflexão sobre se, no terço resguardado para os Juízes dos Tribunais Regionais Federais, ou no terço reservado para os Desembargadores dos Tribunais de Justiça - vale aqui observar a diferença nas terminologias, Juízes e Desembargadores - poderiam também compor aqueles Juízes e Desembargadores provenientes do quinto previsto no art. 94, da $\mathrm{CF} / 88$.

Isto porque se assim for, e vem sendo, mais restritos serão os espaços para os juízes provenientes de concursos públicos, que assumiram a sua investidura com base em critérios 
exclusivamente técnicos. Sem a experiência política anterior, poderão não ter a dinâmica suficiente para concorrer em equivalência para o terceiro grau.

Assim, o critério misto, associativo e partidário, não apenas reservaria o terço direto que lhe foi constitucionalmente resguardado, mas também teria uma reserva relativa indireta, decorrente dos outros dois terços, porquanto possam participar do certame aqueles Juízes e Desembargadores originários do critério do quinto constitucional, onde o modo de investidura também era o misto, associativo e político-partidário.

Também é importante destacar o critério constitucional de recrutamento dos Ministros do Supremo Tribunal Federal do Brasil, consignado no art. 101, da Constituição da República. Note-se que, embora não se trate de um puro Tribunal Constitucional, porquanto tenha competências mais amplas, efetivamente também exerce esta função.

Art. 101. O Supremo Tribunal Federal compõe-se de onze Ministros, escolhidos dentre cidadãos com mais de trinta e cinco e menos de sessenta e cinco anos de idade, de notável saber jurídico e reputação ilibada.

Parágrafo Único. Os Ministros do Supremo Tribunal Federal serão nomeados pelo Presidente da República, depois de aprovada a escolha pela maioria absoluta do Senado Federal.

Embora mais adiante, quanto ao critério de investidura, venha a se desenvolver um estudo comparativo entre o Supremo Tribunal Federal do Brasil e outras Côrtes Constitucionais, desde já recebe relevo a opção do legislador constituinte da Constituição Brasileira de 1988, atribuindo ao Presidente da República (Executivo) e ao Senado Federal a liberdade de escolha, firmando as autoridades máximas que, no Brasil, compõem o Poder Judiciário, sem estabelecer-lhes mandatos nem fixar origens para a designação.

Não há percentuais para juízes de carreira, nem percentuais que expressamente estejam resguardados aos partidos políticos, às universidades, às casas legislativas etc.

É bem verdade que, no Brasil, também há as chamadas jurisdições com competências especiais: a militar (CF/88, arts. 122/124), a eleitoral (CF/88, arts. 118/121) e a trabalhista (CF/88, arts. 111/117); todas integrantes do Poder Judiciário.

Contudo, é possível afirmar que é o critério político ou o critério misto que são os utilizados para a constituição das instâncias superiores do Poder Judiciário brasileiro. 
Embora isto não surpreenda aqueles que lidam diretamente com o Judiciário nacional, creio que razoável parcela da população não tenha ainda a consciência disto.

Também é importante que se reflita que, por qualquer critério, será possível escolherse autoridades judiciais íntegras e competentes.

A questão é saber se é oportuno falar em mudanças.

Afinal, a venda de sentenças e acórdãos vem se tornando um assunto lamentável, e preocupantemente repetitivo, e o tema da investidura não parece que deva passar ao largo.

Reforçando a importância deste tema na formação de uma cidadania consciente, cabe lembrar de que foi, ou vem sendo, objeto de investigação no Brasil casos como o do Presidente do Tribunal de Justiça de um importante Estado brasileiro, de Ministros de Tribunais Superiores, de Desembargadores de Tribunais de Justiça, de Juízes de Tribunais Regionais Federais etc.

Efetivamente, contudo, verifica-se uma grande apatia da sociedade civil, salvo engano, não provocando temor naqueles que optam pelo caminho dos lobbies ilícitos.

Normalmente, são descobertos mediante interceptações telefônicas; gravações em filmes, por vezes, também sonoros e requisição de documentos bancários.

A utilização de confissões, provas testemunhais ou a convocação dos corruptores para denunciar os corruptos são situações anômalas, ou mesmo impossíveis, pois, quase sempre, não é do interesse dos corruptores abrir mão de uma importante fonte de lucro.

Mas o lobby não é algo necessariamente negativo ou ilícito.

Por exemplo, cabe lembrar de, no Supremo Tribunal Federal, ter havido o embate sobre o aborto para grávidas de fetos sem cérebro. De um lado, a igreja católica utilizando a sua força e prestígio para solicitar o apoio dos ministros contra a interrupção da gravidez. De outro, entidades feministas que, a título da defesa dos direitos humanos, buscavam convencer os ministros do contrário.

Mensagens eletrônicas, cartas tradicionais, encaminhamento de livros, fotos e relatos de casos de bebês nascidos sem cérebro, pareceres médicos, e, até mesmo, os lobbies nos gabinetes foram estratégias empregadas, parte a parte, de maneira a refletir o clamor popular sobre o assunto. 
Visitas de ex-ministros do Supremo Tribunal Federal, ligados ao Clero, foram feitas aos atuais ocupantes buscando convencê-los. Contrapondo-se a isto, outros lembravam de um Estado democrático e laico não poder subordinar a interpretação das normas constitucionais a dogmas de fé.

E a necessidade de consciência cívica não é alertada apenas por questões substancialmente envolventes, tal como o aborto de anencéfalos ou o pagamento de contribuições previdenciárias por pessoas já aposentadas; mas também por outras tecnicamente reveladoras do enorme poder de decisão e de modulação, inclusive temporal, dos atuais acórdãos de uma Côrte Constitucional, a saber:

a) leis podem ser consideradas nulas pela Côrte Constitucional, e, mesmo assim, continuar a produzir efeitos. Uma espécie de aplicação do adágio de que é melhor evitar o mal maior, tal como seria reconhecer a inconstitucionalidade do salário mínimo, pois o seu valor fixado não atenderia às necessidades vitais básicas do trabalhador e as de sua família nos setores da moradia, alimentação, educação, saúde, lazer, vestuário, higiene, transporte e previdência social (art. 7., inc. IV, CF/88), e, mesmo assim, autorizar a continuidade da sua aplicação. Seria tal como dizer: a situação ruim deve subsistir se o melhor não puder ser alcançado;

b) as chamadas "situações ainda constitucionais", que, embora incompatíveis com a Constituição, perdurariam por um certo tempo. Seria o caso de admitir que a defensoria pública não deveria ter prazo em dobro, em face do princípio processual da igualdade de armas, mas, diante da sua real falta de estrutura, que o prazo duplo permaneça até que se venha a estruturá-la. Uma espécie de apelo ao legislador para que o mesmo sensibilize-se. Evidentemente que, acaso não se estabeleça um prazo peremptório de cumprimento, o apelo não irá muito além do aconselhamento; e, acaso se estabeleça, há quem veja nisto uma postura de ativismo judicial, ou de invasão do Poder Judiciário na esfera legislativa;

c) o estabelecimento de diferenças entre prazos decadenciais e prescricionais de contribuições previdenciárias, adotando como critério de modulação de efeitos, para os fins de repetição de indébito ou de recuperação do que foi pago, a data de ajuizamento da ação. Tal foi o caso consignado no Recurso Extraordinário nº $556.664-1$, quando o Supremo Tribunal Federal deliberou por aplicar efeitos ex nunc à sua decisão, esclarecendo que a modulação operava-se, tão-somente, em relação a eventuais repetições de indébitos ajuizadas após a 
decisão assentada na sessão do dia 11.06.2008, não abrangendo, portanto, os questionamentos e os processos já em curso.

Imagine-se tudo isto passando à margem do interesse e do conhecimento da cidadania. Seria inadequado falar-se em Estado democrático de direito; pois, no máximo, caberia chamálo de Estado de direito manco.

Efetivamente, contudo, setores deste Estado e da sociedade, ainda mais em questões que envolvam altas somas financeiras, estariam bem alertas.

Assim, os lobbies estariam forçosamente presentes, não se tratando de uma mera opção a sua existência.

Primeiramente, cogita-se dos tais encontros informais. É evidente que, em uma socieade madura, estes acessos deveriam diminuir ou desaparecer. Afinal, cafés, bares, restaurantes etc., utilizados como pontos de encontro fora dos horários de expediente, provocariam, na melhor das hipóteses, dúvidas sobre a técnica e o conteúdo dos julgamentos.

As atuais regras de deontologia e a necessidade de transparência no agir público mantêm importantes reservas contra estes procedimentos, que trazem em si uma aparência de suspeição.

Evidentemente que os lobbies, a depender da relevância do tema, terminarão por ocorrer, mas precisa ser feito não apenas nos horários oficiais dos expedientes, mas nos locais profissionais. O descumprimento desta regra de conduta precisa ser sancionado, pois se se pretende influenciar uma orientação pública, isto precisa ser feito em público, e mediante a possibilidade de igualdade de oportunidades perante a outra parte no embate.

Enfim, reconhecendo-se que o objetivo final do lobista é o de analisar, debater e tentar influenciar o conteúdo de um ato jurídico, é provável que ele identifique o público-alvo com bastante antecedência, oferecendo-se para intermediar atividades de recreio. Daí a preocupação com os encontros dos magistrados realizados a preços módicos nas paradisíacas praias brasileiras.

Note-se, contudo, que nem todo lobby tem caráter estritamente político ou social, pois há também aqueles que detêm jaez técnico ou misto, buscando conjugar ambas as características. Recorde-se dos seminários e congressos jurídicos.

Aqui, a situação é ainda mais sutil. Penso que a ampla divulgação pública não apenas do encontro, mas também dos patrocinadores é um meio de permitir a cidadania ativa e 
fiscalizadora. Em um momento histórico onde tanto se fala de controle, esta seria mais uma maneira de produção de transparência.

É evidente que o lobista profissional deterá uma estratégia apurada de atuação, que se assemelhará a uma verdadeira campanha publicitária ou de comunicação social. É o denominado processo de Lasswell, onde cinco fatores irão contribuir para a formação da estratégia: quem, diz o quê, a quem, como e porquê.

É claro que o onde, o quando e a intensidade definirão o plano de abordagem.

Ora, em questões com alto conteúdo financeiro, como é caso das questões tributárias, tudo isto é meticulosamente calculado.

Assim, sendo para os lobbistas tão relevantes as estratégias de comunicação, é mesmo de se esperar a participação de pessoas da imprensa na prática desta atividade.

A indagação que se faz é se isto é ético? Se, dentro deste ponto de vista, é adequada a coexistência entre o jornalismo e o lobby. Esta pergunta tanto mais importância terá quando se avista não apenas notícias jurídicas nos meios de comunicação, mas também com a dimensão que passam a ter as seções e os sites especializados na área jurídica.

É preciso ter a consciência de que as notícias podem não estar ali, e do modo como estão, como uma conseqüência da imparcialidade do órgão, pois, bem ao contrário, pode ser algo deliberado e parcial, não indo além de uma estratégia de influência para propagar argumentos de uma só das partes.

Cabe mesmo o registro de que a imprensa costuma ser o elemento central de uma boa estratégia de lobby.

Assim, se uma classe social ou empresarial quiser uma reforma tributária que lhe beneficie é de extrema importância a habilidade como ela dará visibilidade ao assunto através da mídia.

Logo, a utilização de mensagens fortes (o percentual do PIB que ocupa a carga fiscal de um país, e o não esclarecimento sobre quem está pagando, quem está sonegando e quem simplesmente resvala para a inadimplência; ou a transferência nos preços de valores fiscais cobrados do consumidor, mas não repassados para o Erário); o contacto pessoal com alguns jornalistas formadores de opinião; a visibilidade através de entrevistas do presidente de uma associação ou o convite a altas autoridades judiciais para o recebimento de condecorações fornecidas por grupos, associações ou corporações não podem passar despercebidos. 
Assim, o lobby pode explorar não apenas o lado técnico da defesa de uma tese, mas também um conhecimento maximizado da estrutura, organização e funcionamento do órgão alvo, além da indispensabilidade de contactos pessoais, que precisariam ser conservados regularmente de maneira que se saiba quem é o lobista e quem ele representa. Quanto mais pessoal for o nível de contacto, mais efetivo o resultado e a possibilidade de acesso.

Trata-se, portanto, de uma estratégia de influência. Uma espécie de "contra-poder", pois se a lei preconiza algo que não é da sua conveniência, busca-se uma interpretação judicial que o seja, reorientando-lhe o conteúdo através das margens de influência.

O lobby, por sua vez, não busca a eliminação de um parecer técnico, mas de redimensionar-lhe a substância.

Aí um desafio para a atividade de lobby: fornecer uma solução, contribuir como um técnico e atribuir mais credibilidade à futura decisão, sem, contudo, assediar o julgador.

A atividade de lobby não visa tornar o problema ainda mais complicado, mas de solução mais fácil. Para isto, exige-se competência técnica e uma lógica de excelência. Daí, a qualidade pessoal do lobista, que termina a serviço da estrutura, geralmente empresarial, que ele representa.

Quanto mais alta a instância de julgamento, mais imprescindível é a "lógica de excelência”. Passa a ser prioritária a escolha da personalidade a se fazer representante dos interesses postulados. Um ex-ministro, um ex-senador etc.

Note-se que o lobista pode e deve acreditar no que faz e possuir abertura ao diálogo para não ficar fechado a filiações partidárias. Termina sendo importante que conheça pessoalmente os decisores derradeiros, e tenham, perante estes, credibilidade e competência comprovadas.

Em outras palavras, precisa-se ter experiência. É conveniente que sejam simples nas exposições de modo a facilitar a leitura dos eventuais memoriais apresentados.

Novamente, insista-se: a atividade de lobby não é necessariamente ilícita, e, por isto, precisa ser transparente, desenvolver-se em audiências públicas, e não em contactos informais, dotados de opacidade e de suspeições. Embora as empresas e os seus interesses econômicos sejam os seus principais clientes, não se pode abstrair que já se começa a expandir a grupos ambientais, culturais e de direitos humanos, por exemplo. 
Assim, ao se falar em lobby, é preciso tentar vencer a barreira fixada entre eles, que fazem lobby; e nós, que não fazemos.

É preciso admitir que também a sociedade civil menos apática, e mais dinâmica, necessita tentar sustentar as suas opiniões junto aos poderes públicos. Não apenas perante o executivo e o legislativo, mas perante o judiciário.

Ocorre que, consciente disto, cabe à sociedade buscar os nomes dos lobistas e compreender melhor os seus interesses. Se for possível, reduzir os pontos de confronto e focar os pontos comuns.

Assim, ao invés de imprecar contra os lobbies, até porque eles são inevitáveis, é necessário estar consciente das suas existências e buscar regularizá-los, registrar os lobistas e exigir deles que apontem os interesses que representam.

Para isto, é fundamental a cidadania consciente e operante. Hoje, no Brasil, e em grande parte dos países ocidentais, já se conquistou o "direito de falar", mas ainda se está longe de conquistar o "direito de ser ouvido". É inútil pregar no deserto. Grande parte dos lobistas não são amadores, mas altamente profissionalizados.

Logo, cabe à sociedade civil buscar um papel de destaque, e estar mais consciente de que se falar está fácil, falar e ser ouvido é um desafio e um milagre que não cairá do céu. Direito é luta (Cf. IHERING, 2002, p. 27), e o combate está só começando.

É provável que se afirme que a sociedade civil já esteja caminhando por novos direitos, avançando o lobby dos ambientalistas, da defesa dos direitos dos animais, o lobby dos agricultores, sendo, portanto, estranha a desconfiança contra o instituto dos grupos de pressão. Pois não se trataria de mera troca de favores ou de influências, mas de um efeito da democracia moderna, que não se esgota no simples ato de votar.

O lobista seria uma espécie de facilitador democrático, permitindo à democracia um nova roupagem, um novo ponto de equilíbrio. Assim como a mídia, teria um espaço importante na conformação de um novo Estado democrático de direito.

Em uma realidade onde quase tudo se exerce sob pressão, natural organizá-la no exercício direto ou indireto perante os poderes públicos.

Assim, seria perfeitamente possível compatibilizá-la com o exercício regular da advocacia ou de atividades de consultoria jurídica e conexas. 
Contudo, se assim o for, é necessário e urgente cogitar de uma forma de tornar o exercício da atividade de lobby tão transparente quanto possível; ou melhor, desejável, em favor do referido equilíbrio democrático.

Não é uma tarefa fácil, inclusive porque, nas circunstâncias atuais, dificilmente uma empresa aceitará autoproclamar-se como sendo estritamente de lobistas, pois, progressivamente, esta atividade costuma ser exercitada conjugadamente com outra ou outras. Na área fiscal, certamente, não será diferente.

Assim, é uma questão relevante de estratégia cogitar se o lobby a ser realizado será de base ou de topo, ou mesmo se ambos, sem que, com isto, banalize-se a atividade.

Se a opção "for de base", provavelmente, pretenda-se buscar e utilizar a pressão da opinião pública a influenciar uma determinada decisão. Será preciso refletir sobre a sua utilidade perante aquilo que verdadeiramente pretende-se. Aqui, poderá valer-se de uma utilização maciça dos meios de comunicação social e das demonstrações públicas de que efetivamente conta-se com a razão. A internet poderá ser muito útil, dado a larga utilzação que, cada vez mais, vem sendo objeto.

Se a "opção for de topo", pretende-se pressionar os decisores das instâncias derradeiras, que constituem a hierarquia superior do poder, condicionando-lhes as decisões. Dirige-se diretamente a quem tem o poder de decisão, embora isto possa ser feito utilizandose várias fórmulas.

Pode-se buscar ações meramente informativas, apenas para dar-lhe conhecimento de opiniões ou posições de grupos de relevo naquela sociedade. Pode-se pretender discutir um determinado assunto específico, ou ser institucional ou geral.

Também o tempo de ação será algo variável, pretendendo-se auferir grande visibilidade, ou não.

Assim, assuntos como os transgênicos, opções nucleares de energia, reformas fiscais podem exigir estratégias de lobby segundo planos prévia e detalhadamente definidos.

De alguma forma, a despeito de que os assuntos possam vir a ser novos, o lobby parece ser tão antigo quanto a própria democracia, ou mesmo tão antigo quanto à natureza humana. O que há de novo é a organização com que está vindo a ser exercido.

Os interesses podem ser novos; mas os jogos de influência, não. Afinal, grupos de interesses sempre existiram e continuarão a existir. 
Os encontros nos corredores e nas antecâmaras do Parlamento inglês, nos extertores do século XVIII, dado que o acesso às sessões parlamentares era vedado a estranhos, é uma das origens possíveis do termo lobby.

Outra origem possível do termo refere-se aos locais onde os legisladores reuniam-se, pois, ao entorno, constavam pessoas a defender os mais variados interesses. Assim, o Federal Hall, de Nova York, como o primeiro assento do Congresso Americano em 1789; ou mesmo o Congress Hall, de Filadélfia, nos salões ao redor da Assembléia, também justificam o termo.

Há mesmo quem defenda que a expressão decorreu de uma situação freqüente no século XIX, nos Estados Unidos, mais precisamente em Washington. Um ex-Presidente dos EEUU (1869-1877), Ulysses Grant, possuía o hábito de freqüentar o Hotel Willard, próximo à Casa Branca. Lá, almoçava ou descontraía-se em um bar ao final do dia. Percebendo-se disto, representantes de grupos de interesses o esperavam no hall de entrada. Daí uma outra alternativa para o termo lobby.

O fato é que, embora seja um termo cada vez mais comum, pouco ou quase nada vem sendo, sistematicamente, estudado. Certamente, ele não deixará de existir sob o pretexto de se lançar algo tão produtivo no silêncio.

E se diga que, particularmente, os profissionais da área juídica não podem adotar a postura do não conheço e nunca vi. Afinal, mesmo que o único motor fosse o interesse histórico, seria preciso relembrar William Hull, que foi contratado pelos veteranos do Exército da Virgínia para pressionar o Congresso norte-americano a deferir-lhes pensões pelos serviços na Guerra da Independência; ou mesmo Sam Ward, o chamado "Rei dos lobistas", no século XIX.

Trata-se de uma atividade que consagra, nos anos 30 e 40, Thomas Corcoran, considerado o pai do lobby moderno.

Assim, a teoria política ou jurídica não pode desconhecer a atividade de tentativa de influenciar decisões, quer pela aprovação, quer pela rejeição, pois isto faz parte da democracia, não apenas aquela do passado; mas, também, e cada vez mais organizadamente, do futuro do regime democrático.

Logo, é de se esperar que, entre os advogados, quer de maneira indireta, quer direta, esta atividade venha também a ser exercida, sendo ela a principal, ou não. 
Entre os grandes e médios titulares e gestores de corporações e empresas, esta não deve ser uma atividade desconhecida, pois, além de conduzir contactos com governantes e altas autoridades públicas, podem realizar atividades lobistas ocasionais (grandes festas, eventos esportivos etc. - pois os aproximam das referidas autoridades), que, mesmo que não incorporadas nas estatísticas, merecem ser contabilizadas.

Ex-políticos, ex-altos funcionários administrativos e judiciais, além de dominarem os mecanismos onde representam os interesses corporativos, possuem redes de conhecimentos pessoais que lhes permitem colaborar não apenas com estes interesses, mas também com o exercício da própria atividade de advocacia de uma maneira efetivamente eficiente.

A questão é que isto não deve se manter sob sigilo, pois a colaboração pode ser apenas técnica, porquanto sejam peritos em suas áreas; e não, necessariamente, estando contaminada por carácteres eminentemente políticos.

Podem estar encaminhando idéias novas em face da larga experiência que possuem, e, com isto, exercendo uma pressão indireta em favor das melhores soluções para os problemas sujeitos às decisões. Funcionariam como um intermediário perante o poder público de modo a encaminhar a melhor solução quer para a corporação ou empresa que representam, quer para os interesses regionais ou da própria nacionalidade.

Assim, desde uma proposta de nova legislação até a realização de visitas organizadas em favor da construção de um complexo industrial ou unidade empresarial, o importante é que a decisão lançada caracterize-se pela isenção e pelo interesse público.

Ora, também os meios menos tradicionais não podem ser desprezados. Refiro-me, agora, aos blogues, que constituem uma recente forma de expressão através da INTERNET. Costumam versar sobre um determinado tema (ambiental, jurídico etc.). Assim, em relação também a questões jurídicas podem vir a prestar apoio a uma nova democracia eletrônica.

Atualizados com frequiência, podem vir a constituir jornais digitais temáticos, e que contam com a característica da interatividade, pois qualquer pessoa poderá comentar o conteúdo abordado. Evidentemente que não se pode estimular os falsos blogs, algumas vezes chamados de flogs, pois o carácter anônimo e a eventual falta de seriedade com que são construídos e conduzidos retiram-lhe a credibilidade.

Outros meios eletrônicos também estão em pleno desenvolvimento, tais como o controle dos motores de busca, que terminam por inserir a informação pretendida logo na 
página inicial de resultados, ao ser digitada uma determinada "palavra-chave". Também os telefones celulares, através do uso do sms, ao convocar manifestações cívicas, ou para a presença em conferências, seminários, congressos constituem instrumentos típicos da democracia do século XXI, pois atribuem visibilidade ao tema proposto.

No entanto, é fundamental, mais uma vez, destacar-se a necessidade de uma conduta à altura da seriedade do assunto conduzido.

Quanto aos advogados, indaga-se se, nesta postura de necessária ética e transparência, na qual estaria a atitude de identificar os seus clientes, os valores que recebem e o que fazem para isto, haveria, ou não, a barreira do sigilo.

Até que ponto o sigilo devido aos clientes constituiria realmente uma barreira. É de se imaginar que o advogado padrão também está a serviço da sociedade antes de mais nada, não cabendo a utilização de mídias de sons e de sons e imagens de maneira criminosa ou a encobrir um crime, que constitui uma atitude de confronto com os objetivos sociais mínimos de convivência comunitária.

Enfim, há lobbies políticos e técnicos, sendo direito de todos não apenas o de falarem, mas, sobretudo, o de serem ouvidos.

É, na avaliação de resultados, que se reflitirá sobre o êxito, ou não, da atividade. Assim, os objetivos podem vir a ser atingidos ou não atingidos, e, se atingidos, poderão o ser total ou apenas em parte.

Também esta fase (pós-campanha) costuma ser fundamental para o lobista, não apenas em razão do interesse já defendido, mas em face dos novos interesses que poderão vir a ser, no futuro, perante os mesmos públicos-alvos.

Exige-se a publicidade e a mais ampla visibilidade de um código de conduta que restrinja a percepção de presentes, financiamentos de bens móveis ou imóveis a baixos custos, dádivas; enfim, que, se não provocam a imediata suspeição da autoridade que os recebem, merecem ser acompanhadas por toda a sociedade que acredita em adotar uma postura ativa diante da busca senão da igualdade de resultados, ao menos da igualdade de oportunidades perante os poderes políticos.

\section{REFERÊNCIAS BIBLIOGRÁFICAS}


ABBAgnAnO, Nicola. Teoría de la Argumentación Jurídica - La Teoria del Discurso Racional como Teoria de la Fundamentacion Juridica. Trads. Manuel Atienza e Isabel Espejo. Madri, Suhrkamp, 1989.

AGUIAR DIAS, José de. A Equidade é Poder do Juiz, in RF, vol. 164, fasc. 633, 1956.

AGUIAR, Roberto A R. O que é justiça; uma abordagem dialética. São Paulo, AlfaOmega, 1982.

ABBAgnano, Nicola. Teoría de la Argumentación Jurídica - La Teoria del Discurso Racional como Teoria de la Fundamentacion Juridica. Trads. Manuel Atienza e Isabel Espejo. Madri, Suhrkamp, 1989.

ALDER, John. Constitucional and Administrative Law. London, Macmillan, 1989.

ALESSI, Renato. Sistema istituzionale del diritto amministratitivo italiano. $3^{\text {a }}$ ed., Milano, Giuffrè, 1960.

ALThUSSER, Louis. Montesquieu, A Política e a História. Trad. Luiz Cary e outro, Lisboa, Presença, 1972.

ASCENSÃO, José de Oliveira. O Direito - Introdução e Teoria Geral. Uma perspectiva lusobrasileira. 10ª ed. Coimbra, Livraria Almedina, 1997.

AUTRAN, Manoel Godofredo de Alencastro. Constituição Política do Império do Brasil. Rio de Janeiro, Ed. H. Laemmert \& Cia. 1881.

BARROSO, Luís Roberto. O Direito Constitucional e a Efetividade de suas Normas: limites e possibilidades da Constituição Brasileira. Rio de Janeiro, Editora Renovar, 1990.

BASTOS, Celso Ribeiro e MARTINS, Ives Gandra. Comentários à Constituição do Brasil (promulgada em 5 de outubro de 1988). São Paulo, Ed. Saraiva, 1988.

BATTIFOL, Henri. A Filosofia do Direito. Trad. Eugénio Cavalheiro, $6^{\mathrm{a}}$ ed., Lisboa, Editorial Notícias, 1981.

BETTI, Emilio. Teoria Generale Della Interpretazione. $1^{a}$ ed. Milano, Giuffrè, 1955.

BIELSA, Rafael. El orden politica y las garantias jurisdiccionales (Separacion de Poderes y vigencia del Derecho). Buenos Aires, 1943.

Estudios de derecho público, T. I. Buenos Aires, 1950.

1951.

Estudios de derecho público. Vol. 2, Deerecho Fiscal. Buenos Aires, Depalma,

Compendio de derecho público, constitucional, administrativo y fiscal. Vol. $3^{\circ}$,

Derecho Fiscal. Buenos Aires, Depalma, 1952.

Democracia Y Republica. Edición póstuma. Buenos Aires. Ediciones Depalma. 
1985.

BOBBIO, Norberto. L’Analogia nella logica del Diritto. Turim, Istituto Giuridico, 1938.

Studi per una Teoria Generale del Diritto. Torino, Giappichelli, 1970.

Teoria della Norma Giuridica. Torino, Viretto, 1958.

. Teoria General del Derecho. Tradução de Eduardo Rozo Acunã. Bogotá, Editorial Temis, 1987.

BONAVIDES, Paulo. Reflexões: Política e Direito. $2^{\mathrm{a}}$ ed. Rio de Janeiro, Editora Forense, 1978.

Curso de Direito Constitucional. $7^{\text {a }}$ ed. São Paulo, Malheiros, 1997.

CAETANO, Marcello. Manual de Ciência Política e Direito Constitucional, vol.1. Lisboa, Coimbra Editora, 1972.

Manual de Ciência Política e Direito Constitucional. Tomo I. $6^{\mathrm{a}}$ ed. revista e ampliada por Miguel Galvão Telles. Coimbra, Livraria Almedina, 1983.

CARNELUTTI, Francesco. Teoria Geral do Direito. Trad. A Rodrigues Queiró e outro. São Paulo, Editora Saraiva, 1942.

CARRAZZA, Roque Antônio. Curso de Direito Constitucional Tributário. $2^{\mathrm{a}}$ ed. revista e ampliada e atualizada pela Constituição Federal de 1988. São Paulo, Editora Revista dos Tribunais, 1991.

DOGGART, Caroline. Paraísos Fiscais. 10ª ed.. Porto. Vida Económica, 2003.

DUARTE, Maria Luísa. União Européia e Direitos Fundamentais - no espaço da internormatividade. Lisboa, 2006.

FRANCO, A. L. Sousa. Finanças do Setor Público - Introdução aos Subsectores Institucionais. Aditamento de Actualização. Lisboa. Reimpressão, 2003.

GUEDES, Armando Marques. Ideologias e Sistemas Políticos. Instituto de Altos Estudos Militares. Lisboa, 1981.

IHERING, Rudolf Von. A luta pelo direito. Tradução de Pietro Nassetti. São Paulo: Martin Claret, 2002.

HAURIOU, André; GICQUEL, Jean e GÉLARD, Patrice. Derecho Constitucional e Instuciones Políticas. Trad. José Antonio Gonzalez Casanova. Barcelona - Caracas México. Editorial Ariel, 1979. 
KANTOROWICZ, Hermann. La lucha por la ciencia del Derecho, in La Ciencia del Derecho, vários autores, Buenos Aires, 1949.

KELSEN, Hans. Teoria General del Derecho y del Estado. Trad. Eduardo Garcia Maynez. 2a. ed., México, Editora Imprenta Universitária, 1958.

. Teoria Geral do Direito e do Estado. Trad. Luís Carlos Borges. São Paulo, Martins Fontes, Editora Universidade de Brasília, 1990.

MEIRELES, Isabel, organizadora. União Européia Tratados - Alterados pelo Tratado de Lisboa. DisLivro. Lisboa, 2007.

MIRANDA, Francisco Cavalcanti Pontes de. Introdução à política científica e os fundamentos da ciência positiva do direito. Rio de Janeiro, 1924.

1979.

Democracia, Liberdade, Igualdade (Os três caminhos). 2a ed., Saraiva, São Paulo,

MONTESQUIEU. Do Espírito das Leis. Livro XI. Capítulo VI - Da Constituição da Inglaterra. Introdução de Otto Maria Carpeaux. Trad.Gabriela de Andrada Dias Barbosa. Rio de Janeiro, Editora Tecnoprint S.A - Ediouro, 1990.

MONTEIRO, André. et al. Olhares em Pernambuco. $2^{a}$ ed. revista e ampliada. R. Souza. Recife, 2007.

MORAIS, Luís D. S. et al. Direito Internacional Económico - uma introdução. Volume II. aafdl. Lisboa, 2007.

NABIAS, José Casalta. Direito Fiscal. $4^{\text {a }}$ ed. Coimbra. Almedina, 2008.

NOGUEIRA, Ruy Barbosa. Da Interpretação e da Aplicação das Leis Tributárias. São Paulo, 1963.

NOVAIS, Jorge Reis. Contributo para uma Teoria do Estado de Direito - do Estado de Direito Liberal ao Estado Social e Democrático de Direito. Coimbra, Livraria Almedina, 1987.

OLIVEIRA, Mauro Márcio. Fontes de Informações sobre a Assembléia Nacional Constituinte de 1987. Quais são, onde buscá-las e como usá-las. Brasília. Editor Subsecretaria de Edições Técnicas do Senado Federal - Secretaria de Documentação e Informação. 1993.

REALE, Miguel. O Direito como Experiência. São Paulo, Editora Saraiva, 1968.

SALDANHA, Nelson. O Poder Constituinte. São Paulo, Editora Revista dos Tribunais, 1986. 
O Estado Moderno e a Separação dos Poderes. São Paulo, Ed. Saraiva, 1987. Ética e História. Rio de Janeiro, Editora Renovar, 1998.

SAMPAIO, Nelson de Souza. As idéias forças da democracia. Bahia, 1941.

O Poder de Reforma Constitucional. Bahia, Liv. Progresso Editora, 1954.

O Processo Legislativo. São Paulo, Editora Saraiva, 1968.

SAN TIAGO DANTAS. Igualdade perante a lei e "due process of law", em problemas de direito positivo. Rio de Janeiro, Editora Forense, 1953.

SANCHES, José Luis Saldanha. A Segurança Jurídica no Estado Social de Direito. Lisboa, Centro de Estudos Fiscais, 1985.

. Manual de Direito Fiscal. $3^{\text {a }}$ ed. Coimbra. Coimbra Editora, 2007.

SCHAFF, Adam. Linguagem e Conhecimento. Coimbra, Livraria Almedina, 1974.

SILVA, José Afonso da. Curso de Direito Constitucional Positivo. 10 a ed., São Paulo, Malheiros Editores Ltda., 1995.

TEIXEIRA, Glória. Manual de Direito Fiscal. Porto. Almedina, 2008.

VIANA, Oliveira. Programa de Revisão da Constituição Federal de 1891, in Problemas de Política Objetiva. Rio de Janeiro, Record, 1974.

O Idealismo da Constituição, in À Margem da História da República. Brasília, Editora Universidade de Brasília, 1980.

VIEHWEG, Theodor. Tópica e Jurisprudência. Madrid, Ed. Taurus, 1964.

. Argumentação jurídica e modelo sistemático na história - a Era Moderna. Trad. de Ferraz Júnior. Trabalho apresentado no Congresso Mundial de Filosofia do Direito e Social, Bruxelas, 1971.

VILANOVA, Lourival. Sobre o Conceito do Direito. Recife, Imprensa Oficial, 1947.

Lógica Jurídica. São Paulo, Bushatsky, 1976.

As Estruturas Lógicas e o Sistema do Direito Positivo. São Paulo, Editora Revista dos Tribunais, 1977.

Causalidade e Relação no Direito. $2^{a}$ ed., São Paulo, Editora Saraiva, 1989.

XAVIER, Alberto. Direito Tributário Internacional. 2a ed. Almedina, 2007.

Vide, ainda, www.ourem.cjb.net 